\title{
Biochemical Characterization of Fast- and Slow-Growing Rhizobia That Nodulate Soybeans
}

\author{
MICHAEL J. SADOWSKY,${ }^{1}$ HAROLD H. KEYSER, ${ }^{2}$ AND B. BEN BOHLOOL ${ }^{1 *}$ \\ Department of Microbiology, University of Hawaii, Honolulu, Hawaii $96822^{1}$ and Nitrogen Fixation \\ Laboratory, United States Department of Agriculture, Beltsville, Maryland $20705^{2}$
}

\begin{abstract}
Fast-growing, acid-producing soybean rhizobia were examined to determine their biochemical relatedness to each other, to typical slow-growing Rhizobium japonicum strains, and to other fast-growing species of Rhizobium. Although both the fast- and slow-growing soybean rhizobia were positive for catalase, urease, oxidase, nitrate reductase, and penicillinase, the fast-growing strains grouped with other fast-growing species of Rhizobium in that they tolerated $2 \% \mathrm{NaCl}$, were capable of growth at pH 9.5, utilized a large variety of carbohydrates (notably disaccharides), and produced serum zones in litmus milk. In addition, these fastgrowing strains were similar to other fast-growing species of Rhizobium in that they produced appreciable levels of $\beta$-galactosidase and nicotinamide adenine dinucleotide phosphate-linked 6-phosphogluconate dehydrogenase but had no detectable hydrogenase activity. The fast-growing soybean rhizobia share symbiotic host specificity with Bradyrhizobium japonicum, but appear to be related biochemically to the other fast-growing species of Rhizobium.
\end{abstract}

Members of the genus Rhizobium are symbiotic nitrogen-fixing bacteria which are able to invade and form nodules on the roots of leguminous plants. The species in this genus have been divided into two groups $(17,35)$ on the basis of growth rate and effect on the $\mathrm{pH}$ of yeast extract-mannitol (YEM) medium under standard laboratory conditions. The fast-growing rhizobia have mean generation times of 2 to $4 \mathrm{~h}$ and produce a net decrease in the $\mathrm{pH}$ of YEM culture medium, whereas the rhizobia referred to as slow growing have mean generation times of $6 \mathrm{~h}$ and longer and do not lower the $\mathrm{pH}$ of this medium (35).

In the past, the typical slow growers that form nodules on the roots of soybeans (Glycine max) have been referred to as Rhizobium japonicum (17). Recently, these rhizobia have been classified in a new genus, Bradyrhizobium, on the basis of their slow growth rate and other characteristics (16) to distinguish them from the fastgrowing, acid-producing root nodule bacteria which now comprise the genus Rhizobium (15).

Recently, Keyser et al. (20) reported the isolation of fast-growing soybean rhizobia from root nodules and soil collected in the provinces of Shansi, Honan, Shandong, and Shanghai, Peoples' Republic of China (PRC). These isolates reportedly (20) have mean doubling times of 2 to $4 \mathrm{~h}$ and lower the $\mathrm{pH}$ of YEM culture medium (final $\mathrm{pH}$ range, 4.7 to 6.7 ). All strains tested were reported to form effective nitrogen-fixing nodules on wild perennial soybeans (Glyine soja) and on an unbred soybean cultivar from the PRC
(G. $\max \mathrm{cv}$. Peking), but formed ineffective symbioses with most commercial soybean cultivars (20). In this study we used a series of diagnostic tests to examine the fast-growing, acid-producing PRC isolates for their relatedness to each other, to typical slow-growing $R$. japonicum strains, and to other fast-growing rhizobia.

\section{MATERIALS AND METHODS}

Bacterial strains and growth conditions. Fast-growing soybean Rhizobium strains USDA 191, USDA 192 , USDA 193, USDA 194, USDA 201, USDA 205 , USDA 206, USDA 208, USDA 214, USDA 217 , and USDA 257 were isolated from soil or nodules collected in the PRC (20). Slow-growing soybean rhizobium strains PRC 005, PRC 74, PRC 113-2, PRC 121-6, PRC 2031, and PRC B15, were obtained from T. S. Hu, Institute of Soils and Fertilizers, Chinese Academy of Agricultural Sciences, Beijing, PRC. Bradyrhizobium japonicum strains USDA 6, USDA 31, USDA 34, USDA 74, USDA 94, USDA 110, USDA 122, USDA 123, USDA 136, USDA 138, USDA 142, and Y1, Y1a, Y2, Y2a, Y3, K2, K2a, S1, and S1a, were from the United States Department of Agriculture Culture Collection, Beltsville, Md. Rhizobium lupini CC814s and NZP 2037, Rhizobium leguminosarum Nitragin 92A3, Rhizobium phaseoli NZP 5097, and Rhizobium trifolit NZP 560 were obtained from R. M. Greenwood, Department of Scientific and Industrial Research, Palmerston North, New Zealand. R. leguminosarum HI 5-0 was isolated in Hawaii (30). $R$. leguminosarum 6015(pJB5JI) was obtained from P. Hirsch, Max Planck Institut, Köln, Federal Republic of Germany; $R$. phaseoli Bel 7.1 was obtained from E. L. Schmidt, University of Minnesota, Minneapolis; Rhizobium sp. 
strain Tal-82 (which nodulates Leucaena) was obtained from the Niftal Project, Paia, Hawaii; and Rhizobium sp. strain UMKL 19 (which nodulates Leucaena) from W. J. Broughton, Max Planck Institut, Köln, Federal Republic of Germany. Agrobacterium tumefaciens 79 and 101 and Rhizobium sp. strain USDA 3F4a4 (which nodulates Sesbania) were from the U.S. Department of Agriculture, Beltsville, Md. All Rhizobium cultures were maintained on YEM agar slants (34). The agar slants used for maintenance of fast-growing rhizobia contained $0.05 \% \mathrm{CaCO}_{3}$. Agrobacterium cultures were maintained on nutrient agar slants. All cultures were incubated at 28 to $30^{\circ} \mathrm{C}$, stored at $4^{\circ} \mathrm{C}$, and subcultured at least once every month.

Staining, morphology, and cultural characteristics. Cultures were examined for cell morphology and Gram reaction after 3 days of growth in YEM liquid medium. Colony morphology was examined by using cultures that were grown for 6 days on YEM agar containing $0.25 \mathrm{mg}$ of bromthymol blue per liter. Motility was estimated from both YEM liquid and YEM agar cultures and in B5 medium (9). Isolates were identified by using strain-specific fluorescent antibodies prepared by the method of Schmidt et al. (32).

Biochemical tests. Tolerance to $\mathrm{pH}$ extremes was determined by inoculating $10^{7}$ cells per $\mathrm{ml}$ from exponentially growing YEM liquid cultures into tubes containing $10-\mathrm{ml}$ portions of YEM liquid media which

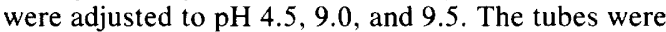
incubated at $30^{\circ} \mathrm{C}$ for 14 days and scored for growth. Tests were performed in triplicate.

Tolerance to sodium chloride was determined on YEM agar plates containing $2.0 \% \mathrm{NaCl}$. The plates were inoculated with $10^{8}$ cells, and the growth was scored after 14 days at $30^{\circ} \mathrm{C}$. Tests were done in triplicate.

For growth reactions in litmus milk (Difco Laboratories, Detroit, Mich.), tubes $(10 \mathrm{ml} /$ tube) were incubated in quadruplicate for 6 weeks at $30^{\circ} \mathrm{C}$ and examined for $\mathrm{pH}$ changes, reduction of litmus, and peptonization (serum zone formation).

Production of 3-ketolactose was determined by the method of Bernaerts and De Ley (1). A. tumefaciens was used as a positive control for this test.

To examine gelatinase activity, exponential-phase cultures from YEM liquid medium were swabbed onto the surfaces of tryptone-yeast extract agar plates (12) containing $0.4 \%(\mathrm{wt} / \mathrm{vol})$ gelatin (Difco). The plates were incubated at $28^{\circ} \mathrm{C}$ for 7 days. A positive reaction was indicated by a clearing zone surrounding the growth of the organism.

The $\mathrm{pH}$ reactions of isolates on agar plates were determined by using YEM medium containing $0.25 \mathrm{mg}$ of bromthymol blue per liter.

Urease activity was determined on urea agar slants (4) that were incubated for 7 days at $28^{\circ} \mathrm{C}$.

Citrate utilization was determined on the solid medium of Koser (22). Plates were inoculated with $10^{8}$ cells, incubated at $30^{\circ} \mathrm{C}$ for 14 days, and examined for growth.

Penicillinase ( $\beta$-lactamase) was detected by the method of Foley and Perret (6).

Oxidase was determined by using the method of Kovaks (23); catalase was determined by the method of Graham and Parker (11)
Hydrogen sulfide production was determined on agar slants (13). The slants were inoculated and examined for $\mathrm{H}_{2} \mathrm{~S}$ after incubation for 14 days at $28^{\circ} \mathrm{C}$.

Nitrate reduction was tested as described in the Manual of Methods for General Bacteriology (33) by using the medium of Graham and Parker (11).

For carbohydrate utilization tests, the basal medium used was that of Bishop et al. (2); different carbohydrates were substituted for mannitol, and $\mathrm{KNO}_{3}(0.6$ $\mathrm{g} /$ liter) was used as the nitrogen source. The medium was solidified with purified agar (Difco). All carbohydrates except dextrin and starch were filter sterilized (pore size, $0.4 \mu \mathrm{m}$; Nuclepore Corp., Pleasanton, Calif.) before they were added to cooled, melted agar medium. Dextrin and starch were added to the medium before it was sterilized at $100^{\circ} \mathrm{C}$ for $15 \mathrm{~min}$. Each carbohydrate was added to a final concentration of $1.0 \%(\mathrm{wt} / \mathrm{vol})$. Inocula were prepared by removing cells from YEM agar slants with a cotton swab and suspending the cells to a density of approximately $10^{7}$ cells per $\mathrm{ml}$ in sterile distilled water. A 10 -fold dilution of each cell suspension was added to the wells of a multiple inoculator plate (18) and inoculated onto the surfaces of carbohydrate-containing agar plates. Bishop agar plates without carbohydrate served as controls. Duplicate plates of each carbohydrate were incubated at $28^{\circ} \mathrm{C}$ for 7 days and scored for growth.

Enzyme assays. 6-Phosphogluconate dehydrogenase (6 PGD) activity was determined in cultures that were grown for $72 \mathrm{~h}$ at $26^{\circ} \mathrm{C}$ in yeast extract-glucose medium (19). The cultures were centrifuged at $6,000 \times g$ for 10 min at $4^{\circ} \mathrm{C}$, and the cells were washed twice in $0.05 \mathrm{M}$ sodium phosphate buffer ( $\mathrm{pH} 7.4)$. The cell pellets were suspended in the same buffer containing $2 \times 10^{-4}$ M 2-mercaptoethanol (27) to a final concentration of $1.0 \mathrm{~g}$ (wet weight) of cells per $1.5 \mathrm{ml}$ of buffer and then disrupted by two passages through a French pressure cell at $15,00016 \mathrm{lb} / \mathrm{in}^{2}$. The cell debris was removed by centrifugation at $14,000 \times g$ for $30 \mathrm{~min}$ at $4^{\circ} \mathrm{C}$. The clear supernatant was stored at $-20^{\circ} \mathrm{C}$ until it was used. The activity of nicotinamide adenine dinucleotide phosphate (NADP)-linked 6PGD (EC 1.1.1.43) was measured by following the reduction of NADP, using the method of Martinez-de Drets and Arias (28). The apparent endogenous enzyme activity was subtracted from the results. Specific activities were expressed as nanomoles of reduced NADP formed per minute per milligram of protein at $25^{\circ} \mathrm{C}$. Protein was determined by the method of Lowry et al. (26), using bovine serum albumin as the standard.

$\beta$-Galactosidase activity was determined in cultures that were grown for 3 days at $26^{\circ} \mathrm{C}$ in tryptone-yeast extract medium containing $0.5 \%(\mathrm{wt} / \mathrm{vol})$ lactose. The cells were centrifuged and washed as described above and then suspended in $0.05 \mathrm{M}$ sodium phosphate buffer ( $\mathrm{pH} 7.2$ ) to a final concentration of $1.0 \mathrm{~g}$ (wet weight) per $3.0 \mathrm{ml}$ of buffer and broken by passage through a French pressure cell at $15,000 \mathrm{lb} / \mathrm{in}^{2}$. The cell debris was removed as described above, and the supernatant fractions were stored at $-20^{\circ} \mathrm{C}$ until they were used. Enzyme activity was measured by following the appearance of $o$-nitrophenol at $420 \mathrm{~nm}$. The incubation mixture $(4.8 \mathrm{ml})$ contained $2.7 \mathrm{ml}$ of enzyme reaction buffer $(0.1 \mathrm{M}$ sodium phosphate buffer [pH 7.0], 10 $\mathrm{M} \mathrm{MgSO}_{4} \cdot 7 \mathrm{H}_{2} \mathrm{O}, 2 \times 10^{-4} \mathrm{M} \mathrm{MnSO}_{4}, 0.05 \mathrm{M} 2-$ mercaptoethanol), $1.8 \mathrm{ml}$ of an $o$-nitrophenyl- $\beta$-Dgalactopyranoside solution $(0.1 \mathrm{M}$ sodium phosphate 
buffer $[\mathrm{pH} 7.0], 1.3 \times 10^{-2} \mathrm{M} o$-nitrophenyl- $\beta$-Dgalactopyranoside [Sigma Chemical Co., St. Louis, Mo.]), and $0.3 \mathrm{ml}$ of cell-free extract. Enzyme assays were carried out at $37^{\circ} \mathrm{C}$, and the reactions were stopped by adding $1.3 \mathrm{ml}$ of reaction stop buffer $(8.0 \mathrm{M}$ urea, 1.0 $\mathrm{M} \mathrm{Na}_{2} \mathrm{CO}_{3}$, pH 12.0). Enzyme activities were expressed as micromoles of $o$-nitrophenol produced per minute per milligram of protein at $37^{\circ} \mathrm{C}$. Corrections were made for absorbance values obtained in controls without substrate.

Hydrogen evolution and the hydrogenase (hydrogen uptake) activities of the fast-growing strains were measured in the bacteroid state as described by Keyser et al. (21). Soybean plants (G. max cv. Peking) were inoculated with cultures of rhizobia in Leonard jar containers (24) and grown in a plant growth chamber. Plant root nodules were harvested after 28 days. All treatments were sampled during peak nitrogenase activity (range 19 to $32 \mathrm{~mol}$ of $\mathrm{C}_{2} \mathrm{H}_{2}$ reduced per g [fresh weight] of nodules per $h$ ). Hydrogen evolution was expressed as micromoles of $\mathrm{H}_{2}$ evolved per gram (fresh weight) of nodules per hour. Hydrogenase activity was expressed as micromoles of $\mathrm{H}_{2}$ oxidized per gram (fresh weight) of nodules per hour.

\section{RESULTS}

Morphological and cultural characteristics. Both the fast- and slow-growing soybean rhizobia were gram-negative, nonsporeforming, rodshaped bacteria. The cells from late-log-phase to stationary-phase YEM cultures of fast growers tended to become enlarged and exhibited marked pleomorphism. Only 1 to $5 \%$ of the cells of the fast-growing soybean rhizobia were motile in young (1- to 2-day-old) YEM cultures, whereas 80 to $90 \%$ of the slow-growing rhizobia were motile. However, when the organisms were grown on a moist B5 agar medium surface (9), a greater percentage (up to $25 \%$ ) of the fastgrowing soybean rhizobia were motile. On YEM agar plates containing bromthymol blue, both fast- and slow-growing rhizobia formed circular, convex, colonies. After 6 to 7 days, the colonies of the fast growers were between 1.0 and $5.0 \mathrm{~mm}$ in diameter and produced acid reactions, whereas the colonies of the slow growers were approximately 0.5 to $1.0 \mathrm{~mm}$ in diameter and produced alkaline reactions. In contrast to a large number of other fast-growing rhizobia, the fast-growing soybean strains did not a produce much extracellular polysaccharide on YEM agar. Two of the strains (USDA 191 and USDA 192) produced watery colonies. Upon repeated restreaking, some of the fast growers produced a second type of colonies which were somewhat smaller than the colonies produced by the parent cultures. These colonial variants were not always stable. Several of the variants that did appear to be stable were isolated from seven strains of fast growers (USDA 191, USDA 192, USDA 193, USDA 208, USDA 214, USDA 217, and USDA 257) and tested for serological affinity by using strain-specific fluorescent antibodies and for effectiveness on soybeans (G. $\max \mathrm{cv}$. Peking). These variants were found to be identical to the parental strains.

Growth responses. Both fast- and slow-growing soybean rhizobia were examined for the ability to grow in the presence of $2.0 \% \mathrm{NaCl}$ and at $\mathrm{pH}$ extremes of 4.5 and 9.5. As Table 1 shows, the fast growers were uniformly sensitive to the low $\mathrm{pH}$ and tolerant of the high $\mathrm{pH}$, whereas the reverse was found for the slow growers. The slow growers grew poorly at $\mathrm{pH} 9.0$ and not at all at $\mathrm{pH} 9.5$, whereas the fast growers grew well at $\mathrm{pH} 9.5$. Conversely, the slow growers grew well at $\mathrm{pH} 4.5$, whereas the fast growers did not grow at this $\mathrm{pH}$. The fast- and slow-growing rhizobia also demonstrated a clear difference in tolerance to $2 \% \mathrm{NaCl}$. Although all of the fastgrowing isolates examined were able to grow in the presence of this salt, there was variation among the strains in the extent of growth. A few strains (USDA 193, USDA 194, USDA 201, and USDA 257) produced a confluent lawn of growth on the medium, whereas others (USDA 191, USDA 192, USDA 205, USDA 206, USDA

TABLE 1. Biochemical characteristics of fast- and slow-growing soybean rhizobia

\begin{tabular}{|c|c|c|}
\hline \multirow{2}{*}{ Characteristics } & \multicolumn{2}{|c|}{$\begin{array}{l}\% \text { of isolates giving positive } \\
\text { reaction }^{a}\end{array}$} \\
\hline & $\begin{array}{l}\text { Slow-growing } \\
\text { rhizobia }\end{array}$ & $\begin{array}{l}\text { Fast-growing } \\
\text { rhizobia }\end{array}$ \\
\hline Catalase production & 100 & 100 \\
\hline Oxidase production & 100 & 100 \\
\hline Urease production & 100 & 100 \\
\hline Penicillinase production & 71 & 100 \\
\hline Nitrate reduction & 100 & 100 \\
\hline 3-Ketolactose production ${ }^{b}$ & 0 & 0 \\
\hline $\mathrm{H}_{2} \mathrm{~S}$ production & 0 & 0 \\
\hline Citrate utilization ${ }^{b}$ & 0 & 0 \\
\hline Gelatinase production $^{b}$ & 0 & 100 \\
\hline $2 \% \mathrm{NaCl}$ tolerance $\mathrm{c}^{\mathrm{c}}$ & 0 & 100 \\
\hline $\mathrm{pH} 4.5$ tolerance ${ }^{c}$ & 100 & 0 \\
\hline pH 9.0 tolerance $^{c}$ & 0 & 100 \\
\hline pH 9.5 tolerance $^{c}$ & 0 & 100 \\
\hline
\end{tabular}

${ }^{a}$ Unless otherwise indicated below, seven slowgrowing strains (PRC 005, PRC 113-2, PRC 121-6, PRC 2031, PRC B15, USDA 110, and USDA 136) and eight fast-growing strains (USDA 192, USDA 193 , USDA 194, USDA 201, USDA 205, USDA 206, USDA 208, and USDA 214) of soybean rhizobia were examined.

${ }^{b}$ These tests also included fast-growing soybean rhizobium strains USDA 191, USDA 217, and USDA 257.

c Fast-growing soybean rhizobium strains USDA 191, USDA 192, USDA 193, USDA 194, USDA 201 , USDA 205, USDA 206, USDA 208, USDA 214, USDA 217 , and USDA 257 and slow-growing soybean rhizobium strains USDA 34, USDA 110 , USDA 122 , and USDA 138 were examined. 
208, USDA 214, USDA 217) yielded individually tolerant colonies. In contrast, none of the slowgrowing $R$. japonicum strains grew in $2 \% \mathrm{NaCl}$.

Biochemical attributes. Table 1 shows that both the fast- and slow-growing rhizobia were catalase, oxidase, and urease positive. All of the strains examined except slow-growing strains PRC 2031 and PRC B15 produced penicillinase, and all strains reduced nitrate. None of the strains produced 3-ketolactose from lactose, produced hydrogen sulfide, or utilized citrate as a sole source of carbon.

The two groups exhibited a marked difference in gelatinase activity. The fast-growing soybean strains produced a clearing zone on tryptoneyeast extract-gelatin agar, whereas the slow growers were negative for gelatinase activity. No gelatinase activity was detected in $R$. leguminosarum HI 5-0, $R$. leguminosarum $92 \mathrm{~A} 3, R$. phaseoli Bel 7.1, $R$. trifolii NZP 560, or Rhizobium spp. strains USDA 3F4a4 and UMKL 19 (which nodulate Sesbania and Leucaena, respectively) (data not shown). However, a strain which nodulates Leucaena, strain Tal-82, was positive for gelatinase activity.

The litmus milk reactions of the fast- and slow-growing rhizobia were quite varied. With the exception of strain PRC 121-6, the slowgrowing soybean rhizobia (strains USDA 6, USDA 31, USDA 34, USDA 74, USDA 94, USDA 110, USDA 122, USDA 123, USDA 136, USDA 138, USDA 142, Y1, Y1a, Y2, Y2a, Y3, $\mathrm{K} 2$, K2a, S1, and S1a) exhibited no peptonization (serum zone formation) but did exhibit alkaline $\mathrm{pH}$ changes. The fast growers gave a variety of litmus milk reactions; these included acid (strains USDA 191, USDA 192, USDA 214, and USDA 257) and alkaline (strains USDA 193, USDA 194, and USDA 201) pH changes accompanied by peptonization, an alkaline $\mathrm{pH}$ change with a lack of peptonization (strain USDA 208), and no $\mathrm{pH}$ change with peptonization (strains USDA 205, USDA 206, and USDA 217). The fast-growing rhizobia tended to reduce litmus (strains USDA 191, USDA 192, USDA 194, USDA 201, USDA 214, USDA 217, and USDA 257), whereas the slow growers did not. Two fast-growing strains from the PRC, strains USDA 193 and USDA 206, peptonized litmus milk only weakly. The other fast-growing rhizobia examined, $R$. phaseoli Bel 7.1, R. phaseoli NZP 5097, and $R$. leguminosarum 92A3 and 6015(pJB5JI), all peptonized litmus milk, had neutral $\mathrm{pH}$ reactions, and were variable for litmus reduction (data not shown).

Carbohydrate utilization. Our carbohydrate utilization tests (Table 2) showed that the fast growers utilized a greater assortment of carbohydrates than the slow growers. All of the organisms examined utilized L-arabinose, D-
TABLE 2. Carbohydrate utilization by fast- and slow-growing soybean rhizobia

\begin{tabular}{lcc}
\hline & \multicolumn{2}{c}{$\begin{array}{c}\% \text { of isolates } \\
\text { showing growth }\end{array}$} \\
\cline { 2 - 3 } Carbohydrates & $\begin{array}{c}\text { Slow- } \\
\text { growing } \\
\text { rhizobia }\end{array}$ & $\begin{array}{c}\text { Fast- } \\
\text { growing } \\
\text { rhizobia }\end{array}$ \\
\hline $\begin{array}{l}\text { L-Arabinose, D-fructose, D- } \\
\text { galactose, D-glucose, D- }\end{array}$ & 100 & 100 \\
$\begin{array}{l}\text { mannitol, D-mannose, L- } \\
\text { rhamnose, D-xylose }\end{array}$ & & \\
$\begin{array}{l}\text { Cellobiose, i-inositol, lactose, } \\
\text { maltose, raffinose, D-glucitol, } \\
\text { sucrose, trehalose }\end{array}$ & 0 & 100 \\
\begin{tabular}{l} 
Dextrin, galactitol, inulin, starch \\
\hline
\end{tabular} & 0 & 0 \\
\hline
\end{tabular}

${ }^{a}$ Eight slow-growing strains (USDA 110 , USDA 123, USDA 136, PRC 005, PRC 113-2, PRC 121-6, PRC 2031, and PRC B15) and ten fast-growing strains (USDA 191, USDA 192, USDA 193, USDA 194, USDA 201, USDA 205, USDA 206, USDA 208, USDA 214, and USDA 217) of soybean rhizobia were examined.

fructose, D-galactose, D-glucose, D-mannitol, Dmannose, L-rhamnose, and D-xylose. Although the fast-growing soybean rhizobia were capable of utilizing arabinose, they grew more slowly on this carbon source than the slow growers. Only the fast-growing soybean rhizobia utilized cellobiose, i-inositol, lactose, maltose, raffinose, Dglucitol, sucrose, and trehalose. None of the organisms examined utilized dextrin, galactitol, inulin, or starch as a sole source of carbon for growth.

NADP-linked 6PGD activity. Table 3 shows that NADP-linked 6PGD activity was detected only in the fast-growing rhizobia. The fast-growing soybean rhizobia had NADP-linked 6PGD activities that ranged from 50 to $181 \mathrm{nmol}$ of NADP reduced per min per $\mathrm{mg}$ of protein. No activity was detected in the nine typical slowgrowing $R$. japonicum strains examined. The five other fast-growing rhizobia examined $(R$. leguminosarum 92A3, $R$. lupini NZP 2037, $R$. trifolii NZP 560, Rhizobium sp. strain Tal-82 and Rhizobium sp. strain USDA 3F4a4) had similarly high specific activities, ranging from 26 to 156 nmol of NADP reduced per min per $\mathrm{mg}$ of protein.

及-Galactosidase activity. Table 3 shows that only the fast-growing rhizobia had appreciable levels of $\beta$-galactosidase activity. In general, the fast-growing soybean rhizobia had $\beta$-galactosidase activities 55 times greater than the slow growers. These levels were comparable to the levels found in the other fast-growing rhizobia examined ( $R$. leguminosarum $92 \mathrm{~A} 3, R$. phaseoli Bel 7.1, $R$. trifolii NZP 560, and Rhizobium sp. strain Tal-82) (data not shown). 
TABLE 3. Enzyme activities of fast- and slowgrowing soybean rhizobia

\begin{tabular}{|c|c|c|c|c|}
\hline \multirow[b]{2}{*}{ Strain } & \multicolumn{4}{|c|}{ Enzyme activities } \\
\hline & $6 \mathrm{PGD}^{a}$ & $\begin{array}{l}\beta \text {-Galacto- } \\
\text { sidase }^{h}\end{array}$ & $\begin{array}{l}\text { Hydrog- } \\
\text { enase }^{r}\end{array}$ & $\begin{array}{l}\mathrm{H}_{2} \text { evo- } \\
\text { lution }\end{array}$ \\
\hline \multicolumn{5}{|l|}{$\begin{array}{l}\text { Slow-growing } \\
\text { rhizobia }\end{array}$} \\
\hline USDA 31 & $<0.5$ & 7.1 & & \\
\hline USDA 110 & $<0.5$ & 3.8 & & \\
\hline USDA 122 & & & 2.5 & 0 \\
\hline USDA 123 & $<0.5$ & 3.0 & & \\
\hline USDA 136 & $<0.5$ & 7.6 & & \\
\hline USDA 138 & $<0.5$ & 3.4 & & \\
\hline PRC 005 & $<0.5$ & 4.2 & & \\
\hline PRC 113-2 & $<0.5$ & 3.3 & & \\
\hline PRC 121-6 & $<0.5$ & 4.8 & & \\
\hline PRC B15 & $<0.5$ & 4.8 & & \\
\hline \multicolumn{5}{|l|}{$\begin{array}{l}\text { Fast-growing } \\
\text { rhizobia }\end{array}$} \\
\hline USDA 191 & 97 & & 0 & 7.3 \\
\hline USDA 192 & 181 & 459 & 0 & 11.4 \\
\hline USDA 193 & 140 & 183 & & \\
\hline USDA 194 & 126 & 101 & 0 & 8.6 \\
\hline USDA 201 & 50 & 345 & 0 & 7.6 \\
\hline USDA 205 & 159 & 97 & 0 & 8.4 \\
\hline USDA 206 & 59 & 261 & 0 & 7.6 \\
\hline USDA 208 & 147 & 383 & 0 & 7.6 \\
\hline USDA 214 & 160 & 245 & 0 & 7.5 \\
\hline USDA 217 & & & 0 & 9.1 \\
\hline
\end{tabular}

${ }^{a}$ Expressed as nanomoles of reduced NADP produced per minute per milligram of protein.

${ }^{b}$ Expressed as micromoles of $o$-nitrophenol produced per minute per milligram of protein.

${ }^{c}$ Expressed as micromoles of $\mathrm{H}_{2}$ oxidized per gram (fresh weight) of nodules per hour.

${ }^{d}$ Expressed as micromoles of $\mathrm{H}_{2}$ evolved per gram (fresh weight) of nodules per hour. One slow-growing strain, USDA 122 , was included for comparison.

Hydrogenase activity. Table 3 shows that none of the fast growers in the bacteroid state had detectable hydrogenase activity, whereas the one slow grower examined, strain USDA 122, expressed this enzyme. Conversely, slow-growing strain $B$. japonicum USDA 122 did not evolve $\mathrm{H}_{2}$, whereas the fast growers had $\mathrm{H}_{2}$ evolution levels that ranged from 7.3 to 11.3 $\mu \mathrm{mol}$ of $\mathrm{H}_{2}$ evolved per $\mathrm{g}$ (fresh weight) of nodules per $h$.

\section{DISCUSSION}

Several diagnostic tests were performed to compare the fast- and slow-growing soybean rhizobia. Our results clearly indicate that the fast growers are quite different biochemically from the slow growers. Although the fast growers share host specificity with the slow growers (both nodulate soybeans, as well as other hosts [20]), they appear to be most similar to the fastgrowing Rhizobium species in their microbiological and biochemical characteristics. However, some characteristics are shared between the two groups of organisms.

All of the fast- and slow-growing soybean rhizobia examined were positive for catalase. oxidase, urease, penicillinase, and nitrate reductase. Both groups were unable to utilize citrate as a sole source of carbon, to produce $\mathrm{H}_{2} \mathrm{~S}$, or to produce 3-ketolactose. Graham and Parker (11) found that most of the $R$. japonicum strains which they tested also possessed several of these attributes. These authors reported that the production of $\mathrm{H}_{2} \mathrm{~S}$ and the utilization of citrate were restricted to some isolates of Rhizobium meliloti. Bernaerts and De Ley (1) found that the production of 3-ketolactose from lactose is limited to species of Agrobacterium, a genus that is closely related to Rhizobium. It is interesting that Graham and Parker (11) found that the production of penicillinase seemed to be restricted mainly to the slow-growing rhizobia, $R$. $j a$ ponicum, $R$. lupini, and Rhizobium spp. of the cowpea miscellany group. However, these authors indicated that some $R$. leguminosarum strains also possess this attribute.

The results of the $\mathrm{pH}$ and salt tolerance tests place the fast-growing soybean rhizobia with other fast-growing rhizobia. Previous studies of rhizobia $(3,8,11,31)$ in pure culture and in soil have shown that the fast growers are relatively more alkali tolerant and acid sensitive than the slow growers. Also, Graham and Parker (11) have shown that among the rhizobia, tolerance to $2 \% \mathrm{NaCl}$ is restricted to the fast-growing species $R$. meliloti. In addition, the responses of the fast-growing soybean rhizobia in litmus milk were typical of the fast-growing Rhizobium species (e.g., $R$. trifolii, $R$. leguminosarum, and $R$. meliloti) $(7,11)$.

Graham and Parker (11) and Fred et al. (7) showed that the fast-growing rhizobia tend to use a wider variety of carbohydrates than the slow growers. This is shown clearly in Table 2; the fast growers used the majority of the carbohydrates examined, and the slow growers used relatively few. It is interesting that the types of carbohydrates utilized also vary among the soybean rhizobia. As pointed out by Glenn and Dilworth (10), slow-growing rhizobia tend to lack both uptake systems and catabolic enzymes for disaccharides. Our results are in agreement with the results of these authors in that the disaccharides cellobiose, lactose, maltose, trehalose, and sucrose and the trisaccharide raffinose were metabolized by fast-growing strains but not by slow-growing rhizobia. Table 3 shows that only the fast-growing soybean rhizobia have appreciable $\beta$-galactosidase activities similar to the activities of the other fast growers examined (data not shown).

Consistent with the division of the rhizobia 
into fast-and slow-growing groups on the basis of carbohydrate utilization is the division of these organisms based on the presence and absence of enzymes of the pentose phosphate pathway. As pointed out by Martinz-de Drets and Arias $(28,29)$, although both fast- and slowgrowing rhizobia have nicotinamide adenine dinucleotide-linked 6PGD activity, only the fast growers have NADP-linked 6PGD activity. Table 3 shows that the fast-growing soybean rhizobia have levels of NADP-linked 6PGD activity that are comparable to the levels of the other fast-growing rhizobia. These results are consistent with those of Martinez-de Drets and Arias $(27,28)$ and Keele et al. (19).

The hydrogenase activities of the fast-growing soybean rhizobia (Table 3 ) are similar to those of other fast-growing species of Rhizobium, which reportedly have low bacteroid hydrogenase activities (5). Furthermore, the hydrogenase activities of culture-grown fast-growing soybean rhizobia (strains USDA 192, USDA 193, USDA 194, USDA 201, USDA 205, and USDA 206) were also found to be very low by the tritium exchange assay of $\operatorname{Lim}(25 ; \mathrm{S}$. Uratsu, personal communication).

In summary, although the fast-growing soybean rhizobia share symbiotic host specificity with the typical slow growers, they appear more closely related, on biochemical bases, to other fast-growing rhizobia. In a series of papers (14), Ishizawa noted the occurrence of fast-growing rhizobia in soybean nodules. We examined one of the isolates of Ishizawa, which was provided by D. C. Jordan. We found (data not shown) that although this isolate is somewhat faster growing than typical slow-growing soybean bacteria, it does not acidify YEM medium and is not at all serologically related to the fast-growing isolates from the PRC. The slow-growing soybean rhizobia are now classified as Bradyrhizobium japonicum (16). Several of the diagnostic tests that were used to describe the fast-growing soybean rhizobia indicated that these newly described organisms do not fit into the genus Bradyrhizobium. Therefore, the taxonomic position of these isolates must logically be in the new genus Rhizobium sensu stricto (15).

\section{ACKNOWLEDGMENTS}

This work was supported in part by grant SEA/AR-58-9 AHZ-2-670 from the U.S. Department of Agriculture and by grants DSAN-6-0100 and USDA RSSA 4-76 from the U.S. Agency for International Development.

We thank D. C. Jordan and R. M. Kosslak for reviewing the manuscript and $\mathrm{M}$. Morimoto for typing.

\section{LITERATURE CITED}

1. Bernaerts, M. J., and J. De Ley. 1963. A biochemical test for crown gall bacteria. Nature (London) 197:406-407.

2. Bishop, P. E., J. G. Guevara, J. A. Engelke, and H. J.
Evans. 1976. Relation between glutamine synthetase and nitrogenase activities in the symbiotic association between Rhizobium japonicum and Glycine max. Plant Physiol. 57:542-546.

3. Bryan, U. C. 1923 . Effects of acid soils on nodule-forming bacteria. Soil Sci. 15:542-546.

4. Christensen, W. B. 1946. Urea decomposition as a means of differentiating Proteus and paracolon organisms from each other and from Salmonella and Shigella types. J. Bacteriol. 52:461-466.

5. Evans, H. J., K. Purohit, M. A. Cantrell, G. Eisbrenner, S. A. Russel, F. J. Hanus, and J. E. Lepo. 1981. Hydrogen losses and hydrogenase in nitrogen-fixing organisms, $\mathrm{p}$. 84-96. In A. H. Gibson and W. E. Newton (ed.), Current perspectives in nitrogen fixation. Australian Academy of Science, Canberra.

6. Foley, J. M., and C. J. Perret. 1962. Screening bacterial colonies for penicillinase production. Nature (London) 195:287-288

7. Fred, E. B., I. L. Baldwin, and E. McCoy. 1932. Root nodule bacteria and leguminous plants. University of Wisconsin Studies in Science, no. 5. University of Wisconsin, Madison.

8. Fred, E. B., and A. Davenport. 1918. Influence of reaction on nitrogen-assimilating bacteria. J. Agric. Res. (Washington, D.C.) 14:317-336.

9. Gamborg, O. L. 1975. Callus and cell culture, p. 1-9. In O. L. Gamborg and L. R. Wetter (ed.), Plant tissue culture methods. National Research Council of Canada, Saskatoon, Saskatchewan.

10. Glenn, A. R., and M. J. Dilworth. 1981. The uptake and hydrolysis of disaccharides by fast- and slow-growing species of Rhizobium. Arch. Microbjol. 129:233-239.

11. Graham, P. H., and C. A. Parker. 1964. Diagnostic features in the characterization of the root-nodule bacteria of legumes. Plant Soil 20:383-396.

12. Hirsch, P. R., J. von Montagu, A. W. B. Johnston, N. J. Brewin, and J. Schell. 1980. Physical identification of bacteriocinogenic, nodulation, and other plasmids in strains of Rhizobium leguminosarum. J. Gen. Microbiol. 120:403-412.

13. Hunter, C. A., and H. G. Crecelius. 1938. Detection of hydrogen sulfide in cultures. J. Bacteriol. 35:185-196.

14. Ishizawa, S. 1953. Studies on the root nodule bacteria of leguminous plants. I. Characters in artificial media. J. Sci. Soil Manure 23:169-172.

15. Jarvis, B. D. W., C. E. Pankhurst, and J. J. Patel. 1982 Rhizobium loti, a new species of legume root nodule bacteria. Int. J. Syst. Bacteriol. 32:378-380.

16. Jordan, D. C. 1982. Transfer of Rhizobium japonicum Buchanan 1980 to Bradyrhizobium gen. nov., a genus of slow-growing root nodule bacteria from leguminous plants. Int. J. Syst. Bacteriol. 32:136-139.

17. Jordan, D. C., and O. N. Allen. 1974. Genus II. Rhizobi um, p. 262-264. In R. E. Buchanan and N. E. Gibbons (ed.), Bergey's manual of determinative bacteriology, 8 th ed. The Williams \& Wilkins Co.. Baltimore.

18. Josey, D. P., J. L. Beynon, A. W. B. Johnston, and J. E. Beringer. 1979. Strain identification in Rhizobium using intrinsic antibiotic resistance. J. Appl. Bacteriol. 46:343350 .

19. Keele, B. B., Jr., P. B. Hamilton, and G. H. Elkan. 1969 Glucose catabolism in Rhizobium japonicum J. Bacteriol. 97:1184-1191.

20. Keyser, H. H., B. B. Bohlool, T. S. Hu, and D. F. Weber. 1982. Fast-growing rhizobia isolated from root nodules of soybean. Science 215:1631-1632.

21. Keyser, H. H., P. van Berkum, and D. F. Weber. 1982. A comparative study of the physiology of symbiosis formed by Rhizobium japonicum with Glycine max, Vigna unguiculata and Macroptilium atropurpureum. Plant Physiol. 70:1626-1630.

22. Koser, S. A. 1923. Utilization of the salts of organic acids by the colon-aerogenes group. J. Bacteriol. 8:493-520.

23. Kovaks, N. 1956. Identification of Pseudomonas pyo- 
cyane $a$ by the oxidase reaction. Nature (London) 178:703.

24. Leonard, L. T. 1943. A simple assembly for use in the testing of cultures of rhizobia. J. Bacteriol. 45:523-527.

25. Lim, S. T. 1978. Determination of hydrogenase in freeliving cultures of Rhizobium japonicum and energy efficiency of soybean nodules. Plant Physiol. 62:609-611.

26. Lowry, O. H., N. J. Rosebrough, A. L. Farr, and R. J. Randall. 1951. Protein measurement with the Folin phenol reagent. J. Biol. Chem. 193:265-275.

27. Martinez-de Drets, G., and A. Arias. 1970. Metabolism of some polyols by Rhizobium meliloti. J. Bacteriol. 103:97103.

28. Martinez-de Drets, G., and A. Arias. 1972. Enzymatic basis for differentiation of Rhizobium into fast- and slowgrowing groups. J. Bacteriol. 109:467-470.

29. Martinez-de Drets, G., and A. Arias. 1977. 6-Phospho-Dgluconate: $\mathrm{NAD}^{+}$2-oxidoreductase (decarboxylating) from slow-growing rhizobia. J. Bacteriol. 130:1139-1143.

30. May, S. N., and B. B. Bohlool. 1983. Competition among
Rhizobium leguminosarum strains for nodulation of lentils (Lens esculenta). Appl. Environ. Microbiol. 45:960-965.

31. Norris, D. O. 1965. Acid production by Rhizobium, a unifying concept. Plant Soil 22:143-166.

32. Schmidt, E. L., R. O. Bankole, and B. B. Bohlool. 1968. Fluorescent antibody approach to the study of rhizobia in soil. J. Bacteriol. 95:1987-1992.

33. Smibert, R. M., and N. R. Krieg. 1981. General characterizations, p. 409-443. In P. Gerhardt, R. G. E. Murray R. N. Costilow, E. W. Nester, W. A. Wood, N. R. Krieg, and G. B. Phillips (ed.), Manual of methods for general bacteriology. American Society for Microbiology, Washington, D.C.

34. Vincent, J. M. 1970 . A manual for the practical study of root-nodule bacteria. IBP handbook 15 . Blackwell Scientific Publications, Oxford.

35. Vincent, J. M. 1974. Root-nodule symbiosis with Rhizobium, p. 265-347. In A. Quispel (ed.), Biology of nitrogen fixation. North-Holland Publishing Co., Amsterdam. 